\title{
Surface characteristics at Dome A, Antarctica: first measurements and a guide to future ice-coring sites
}

\author{
XIAO Cunde, ${ }^{1,2}$ LI Yuansheng, ${ }^{3}$ Ian ALLISON, ${ }^{4}$ HOU Shugui, ${ }^{1}$ Gabrielle DREYFUS, ${ }^{5}$ \\ Jean-Marc BARNOLA, ${ }^{6}$ REN Jiawen, ${ }^{1}$ BIAN Lingen, ${ }^{2}$ ZHANG Shenkai, ${ }^{7}$ \\ Takao KAMEDA ${ }^{8}$
}

\author{
${ }^{1}$ State Key Laboratory of Cryospheric Science, Cold and Arid Regions Environmental and Engineering Research Institute, \\ Chinese Academy of Sciences, Lanzhou 730000, China \\ E-mail: cdxiao@cams.cma.gov.cn \\ ${ }^{2}$ Chinese Academy of Meteorological Sciences, 46 Zhongguancun South Avenue, Beijing 100081, China \\ ${ }^{3}$ Polar Research Institute of China, Shanghai 200129, China \\ ${ }^{4}$ Australian Antarctic Division and Antarctic Climate and Ecosystems CRC, Private Bag 80, Hobart, Tasmania 7001, Australia \\ ${ }^{5}$ Laboratoire des Sciences du Climat et de I'Environnement, Institut Pierre-Simon Laplace, \\ CEA-CNRS-Université de Versailles Saint-Quentin, 91191 Gif-sur-Yvette Cedex, France \\ ${ }^{6}$ Laboratoire de Glaciologie et Géophysique de I'Environnement du CNRS (associé à I'Université Joseph Fourier-Grenoble I), \\ 54 rue Molière, BP 96, 38402 Saint-Martin-d'Hères Cedex, France \\ ${ }^{7}$ Chinese Antarctic Center of Surveying and Mapping, School of Geodesy and Geomatics, Wuhan University, \\ 129 Luoyu Road, Wuhan 430079, China \\ ${ }^{8}$ Kitami Institute of Technology, Koen-cho 165, Kitami 090-8507, Japan
}

\begin{abstract}
An assessment of the glaciological and meteorological characteristics of Dome A, the summit of the East Antarctic ice sheet, is made based on field investigations during the austral summer of 2004/05. Knowledge of these characteristics is critical for future international studies such as deep icecore drilling. The assessment shows that: (1) Dome $\mathrm{A}$ is characterized by a very low $10 \mathrm{~m}$ depth firn temperature, $-58.3^{\circ} \mathrm{C}$ (nearly $3^{\circ} \mathrm{C}$ lower than at EPICA Dome $\mathrm{C}$ and $1^{\circ} \mathrm{C}$ lower than at Vostok). (2) Automatic weather station (AWS) measurements of snow surface height and reference layers in a snow pit indicate the present-day snow accumulation rate at Dome $A$ is within the range $1-3 \mathrm{~cm} \mathrm{w.e.} \mathrm{a}^{-1}$. Densification models suggest a range of $1-2 \mathrm{~cm} \mathrm{w.e.}^{-1}$. This is lower than at other sites along the ice divide of East Antarctica (IDEA). Annual layers at Dome A are thus potentially thinner than at other sites, so that a longer record is preserved in a given ice thickness. (3) The average wind speed observed at Dome $A\left(<4 \mathrm{~m} \mathrm{~s}^{-1}\right)$ is lower than at other sites along IDEA. Together, these parameters, combined with radio-echo sounding data and information on the subglacial drainage distribution beneath Dome $A$, suggest Dome $A$ as a candidate site for obtaining the oldest ice core.
\end{abstract}

\section{INTRODUCTION}

Long ice-core records from Vostok, EPICA Dome C, Dome F and other sites in Antarctica, as well as GRIP, GISP2, NorthGRIP and other sites in Greenland, provide detailed archives of natural climate change. They highlight, in particular, the close linkages between climate and greenhouse gas concentrations over the last eight glacial-interglacial cycles (Petit and others, 1999; Johnsen and others, 2001; EPICA community, 2004). The International Partnership in Ice Core Sciences (http://www.pages.unibe.ch/science/ initiatives/ipics/documents.html) is planning future icecoring activities, with the completion of major projects in Greenland and Antarctica over the next 15 years (Brook and others, 2006). One of the major objectives of the International Partnerships in Ice Core Sciences (IPICS) is to obtain a deep ice core in Antarctica that extends through the mid-Pleistocene transition (MPT), roughly 700-1250 ka (Clark and others, 2006), a time period when Earth's climate shifted from a 41000 year to a 100000 year glacialinterglacial cycle. This transition has been recorded in marine sediments, and may have occurred due to changes in atmospheric greenhouse gas concentrations (Raymo and Ruddiman, 1992). Because ice cores record past greenhouse gas concentrations, the recovery of a core spanning this time period would allow one of the hypotheses of the MPT to be tested.

Dome Argus (Dome A), the summit of the East Antarctic ice sheet, is a point of international interest because of its potential for providing a very long and undisturbed ice-core paleoclimate record (Fig. 1). Yet no in situ surveys of this site had been made until the 21st Chinese National Antarctic Research Expedition (CHINARE-21) visited Dome A in the 2004/05 austral summer. Here we present the preliminary results from these investigations. These results will be useful not only for planning any future ice coring, but also for understanding the meteorological and glaciological characteristics of this data-sparse area of the Antarctic ice sheet.

\section{MEASUREMENT OF SITE CHARACTERISTICS AT DOME A}

Studies at Dome A during CHINARE-21 included: (1) deployment of an automatic weather station (AWS) measuring meteorological characteristics including snow accumulation rate; (2) a radio-echo sounding (RES) survey to detect internal ice layers and ice thickness; (3) recovery of a $110 \mathrm{~m}$ ice core; (4) sampling in a $2.3 \mathrm{~m}$ deep snow pit for determination of snow chemical content and recent snow accumulation rate; 


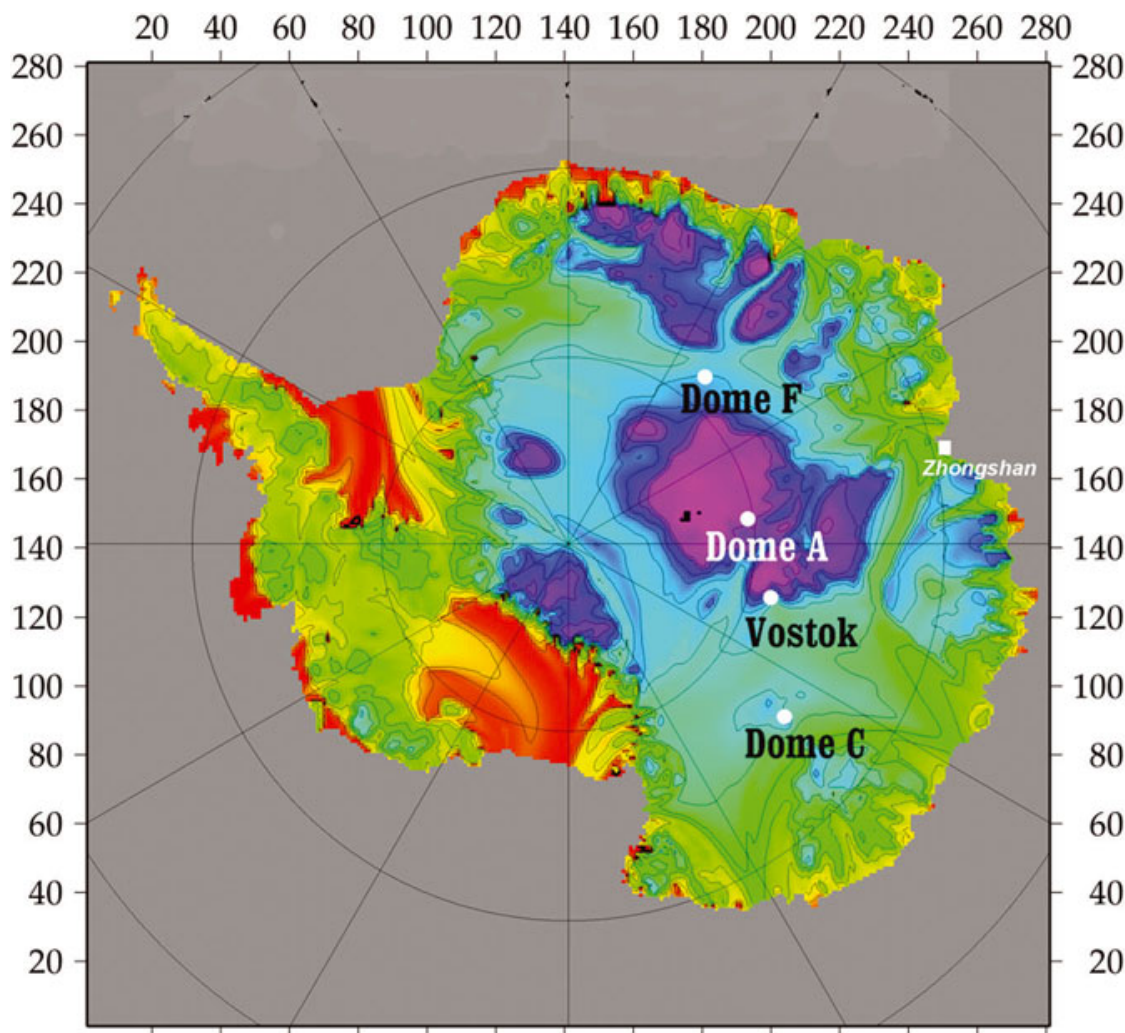

$20 \quad 40 \quad 60 \quad 80100120140160180200220240260280$

Fig. 1. Location of Dome $A$ and other deep ice-coring sites along the ice divide of East Antarctic (IDEA). The distribution of modeled age (ka) of the basal ice at $98.5 \%$ relative depth is from P. Huybrechts (personal communication, 2007) using the model of Rybak and Huybrechts (2003).

and (5) a global positioning system (GPS) survey to determine ice-flow rates and to map surface topography.

The surface topography of the summit region of Dome A was measured by real-time kinematic GPS survey. The position of the summit was determined as $80^{\circ} 22^{\prime} 01.6^{\prime \prime} \mathrm{S}$, $77^{\circ} 22^{\prime} 22.3^{\prime \prime} \mathrm{E}$ at $4092.5 \mathrm{~m}$ a.s.l. (Zhang and others, 2007). The survey defined the topography in the region of the Dome A summit. The lowest surface elevation within the $30 \mathrm{~km} \times 30 \mathrm{~km}$ survey area (with more than 1000 surveyed points) was $4090.2 \mathrm{~m}$, giving an elevation range of only $2.7 \mathrm{~m}$ over the entire area. The surface slope in the summit area is $<0.009 \%$, indicating a very flat and smooth surface. Although repeat GPS measurements to determine the surface flow rate have not yet been made, flow rates are low in the flat inland polar summit regions, and a repeat GPS survey at a site $25 \mathrm{~km}$ from Dome $C$ yielded an ice-flow rate of $0.2 \mathrm{~m} \mathrm{a}^{-1}$ (Cafarella and others, 2006). We expect similarly low values near Dome A.

The AWS deployed at Dome A by CHINARE-21 was designed and built by the Australian Antarctic Division. It takes hourly measurements of air temperature and wind speed (both at nominal heights of 1,2 and $4 \mathrm{~m}$ above the surface), wind direction, atmospheric pressure, relative humidity, incoming solar radiation, surface snow height and subsurface firn temperatures at $0.1,1.0,3.0$ and $10 \mathrm{~m}$ depths. Data are relayed via the Argos system on the US National Oceanic and Atmospheric Administration (NOAA) satellites. More than 2 years of data have been received from this AWS. The AWS sensor specifications are listed in Table 1.

Snow surface height (SSH) was measured every hour with a Campbell Scientific SR50-45 ultrasonic distance sensor mounted on the $4 \mathrm{~m}$ arm of the AWS. The sensor has a field

Table 1. Specifications for the AWS at Dome A

\begin{tabular}{|c|c|c|c|c|}
\hline Sensor & Type & Range & Accuracy & Resolution \\
\hline Air temperature & FS23D thermistor in ratiometric circuit & -10 to $-99^{\circ} \mathrm{C}$ & $0.05^{\circ} \mathrm{C}$ & $0.02^{\circ} \mathrm{C}$ \\
\hline Subsurface temperature & FS23D thermistor in ratiometric circuit & -10 to $-99^{\circ} \mathrm{C}$ & $0.05^{\circ} \mathrm{C}$ & $0.02^{\circ} \mathrm{C}$ \\
\hline Relative humidity & Vaisala HMP35D & $0-100 \%$ & $\begin{array}{l}2 \%(\mathrm{RH}<90 \%) \\
3 \%(\mathrm{RH}>90 \%)\end{array}$ & $2 \%$ \\
\hline Air pressure & Paroscientific Digiquartz 6015A & $530-610 \mathrm{hPa}$ & $0.2 \mathrm{hPa}$ & $0.1 \mathrm{hPa}$ \\
\hline Wind direction & Aanderaa $3590 \mathrm{~B}$ wind vane & $0-360^{\circ}$ & $6^{\circ}$ & $6^{\circ}$ \\
\hline Global radiation & Middleton EP08 pyranometer & $\begin{array}{l}305-2850 \mathrm{~nm} \text { (50\% points) } \\
0-205 \mathrm{MJ}\end{array}$ & $5 \%$ & $0.1 \mathrm{MJ}$ \\
\hline Snow height & Campbell SR50 acoustic ranger & $0.5-5 \mathrm{~m}$ & $0.01 \mathrm{~m}$ or $0.4 \%$ & $0.02 \mathrm{~m}$ \\
\hline
\end{tabular}



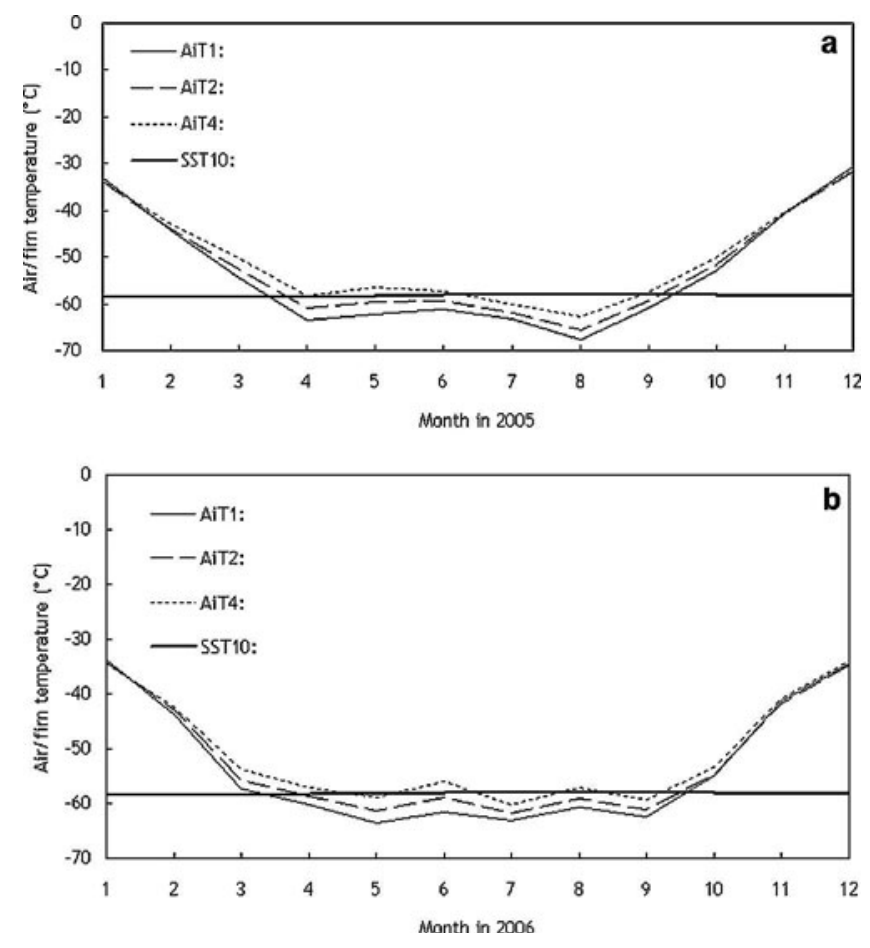

Fig. 2. Monthly means of air and firn temperatures recorded by the AWS at Dome A in 2005 (a) and 2006 (b). AiT1, AiT2, AiT4 and SST10 represent air temperature at 1, 2 and $4 \mathrm{~m}$ heights and subsurface temperature at $10 \mathrm{~m}$ depth respectively.

of view of approximately $22^{\circ}$, and measures the distance to the closest object within this field of view (e.g. the top of the snow surface) with a resolution of $0.02 \mathrm{~m}$. Total snow accumulation is calculated as the difference between the original installed height of the sensor above the surface and subsequent measured distances.

Two RES systems, with frequencies of 179 and $60 \mathrm{MHz}$ respectively (Fujita and others, 1999), were used to detect the internal ice layers and ice thickness along the $1228 \mathrm{~km}$ traverse line from Zhongshan station to Dome A, as well as within an area of $30 \mathrm{~km} \times 30 \mathrm{~km}$ around Dome A. An ice thickness of approximately $3050 \mathrm{~m}$ was located at $80^{\circ} 25^{\prime} 37.2^{\prime \prime} \mathrm{S}, 77^{\circ} 11^{\prime} 58.9^{\prime \prime} \mathrm{E}$. More detailed RES data will be reported elsewhere (personal communication from B. Sun, 2007).

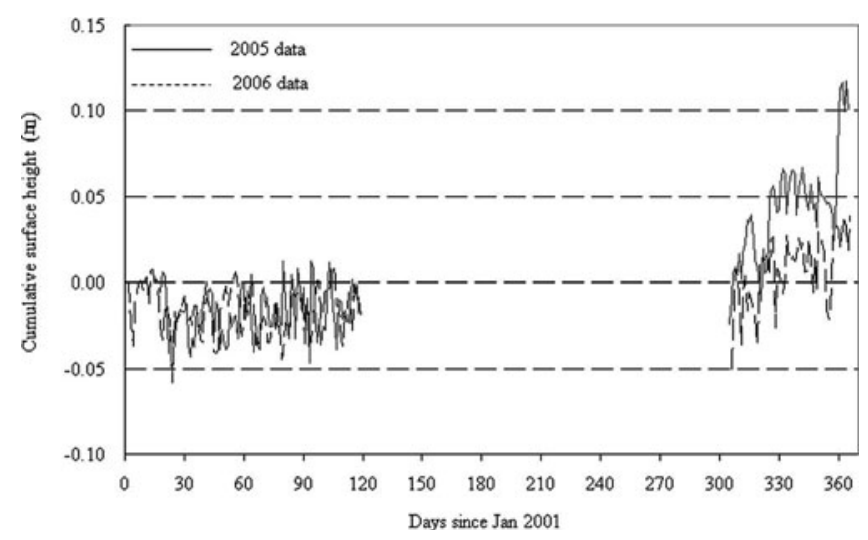

Fig. 3. Daily cumulated snow surface height (snow accumulation) in 2005 and 2006 recorded by the AWS at Dome A.

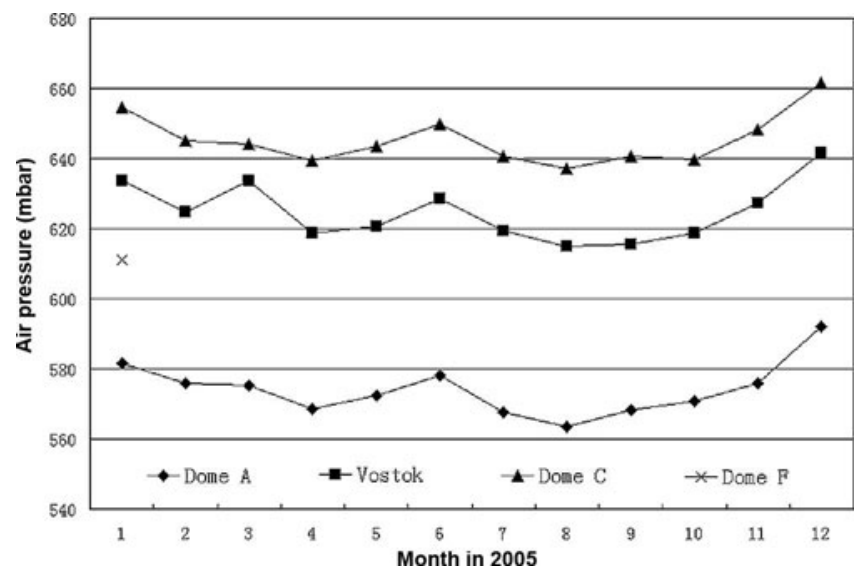

Fig. 4. Monthly average air pressure at several sites along IDEA in 2005. Note that the January value for Dome $F$ is the average over 22 days.

A $110 \mathrm{~m}$ long ice core was recovered from the summit of Dome A. Firn density was measured in situ, and in some samples $\delta \mathrm{D}$, particle concentration and $\mathrm{CH}_{4}$ were measured in laboratories on our return from Antarctica. Samples from a snow pit were measured for chemistry, and to detect atmospheric bomb test horizons (1954-65) from gross $\beta$ activity. These measurements, discussed below, support accumulation estimates and an understanding of snow densification.

\section{RESULTS AND DISCUSSION}

\section{Meteorological features at Dome A}

\section{Air temperature}

At sites on the interior Antarctic ice sheet, the firn temperature at $10 \mathrm{~m}$ depth is nearly constant and has only a slight seasonal fluctuation. Hence, in the dry snow zone where there is no melt or refreezing, the $10 \mathrm{~m}$ firn temperature approximates the annual mean air temperature near the surface (Martin and Peel, 1978; Qin, 1987; US National Snow and Ice Data Center, http://nsidc.org/data/docs/agdc/ thermap/documentation.html). The measured $10 \mathrm{~m}$ firn temperature at Dome $\mathrm{A}$ was $-58.3^{\circ} \mathrm{C}$ in 2005 and $-58.2^{\circ} \mathrm{C}$ in 2006 (Fig. 2), and the monthly deviations from the mean are less than $0.2^{\circ} \mathrm{C}$. During the in situ investigations at Dome A in January 2005, two portable thermometers (produced in China and Japan) were used to measure the $10 \mathrm{~m}$ firn temperature in a borehole over a 24 hour period. They both recorded $-58.3^{\circ} \mathrm{C}$, consistent with AWS records in 2005 and 2006.

Strong surface air-temperature inversions, consistent with the low wind speed at Dome $\mathrm{A}$, were identified. These averaged $1.1^{\circ} \mathrm{C}$ between 1 and $2 \mathrm{~m}$ height, and $1.5^{\circ} \mathrm{C}$ between 2 and $4 \mathrm{~m}$ height, over the 2005-06 period (Fig. 2). The inversion strength reached much higher values for short periods during winter months, and it was not unusual for the air temperature $1 \mathrm{~m}$ above the surface to be more than $10^{\circ} \mathrm{C}$ lower than the temperature $2 \mathrm{~m}$ above the surface. The annual average air temperature for the 2005-06 period at $1 \mathrm{~m}$ height was $-53.0^{\circ} \mathrm{C}$, considerably higher than the firn temperature (Fig. 2). A considerable difference between the air temperature and $10 \mathrm{~m}$ firn temperature was also seen at other Antarctic summit sites, and, although the Dome A difference is exceptionally large, it is in inverse proportion to 

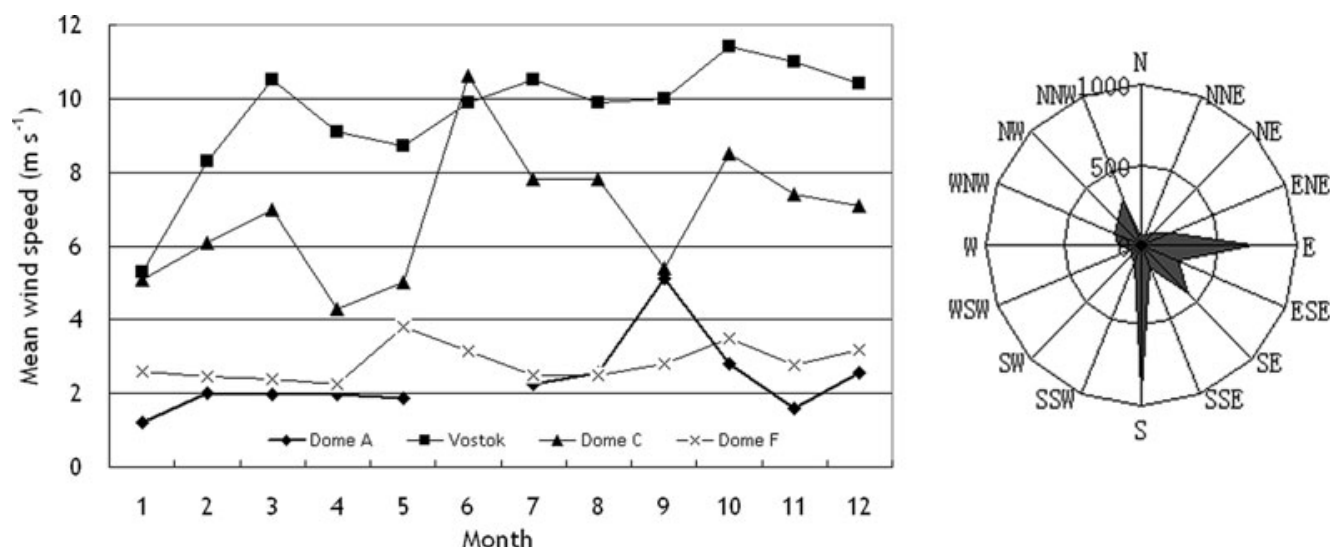

Fig. 5. Wind speed in 2005 for some locations along IDEA. Wind direction at Dome A in 2005 is also shown.

the wind speed at this site compared with others. For 200506 the average air temperature at Dome A was higher than the long-term mean at Vostok, $\left(-53.0^{\circ} \mathrm{C}\right)$ even though the latter site is $600 \mathrm{~m}$ lower. We are not sure at this stage whether this is just a function of the short record available for Dome A, or whether it is a feature of the large-scale atmospheric circulation over the ice sheet.

\section{Snow surface height}

The 2 years of Dome A SSH measurements, after correction for ambient temperature and quality-control checks, are shown in Figure 3. Seasonal SSH variations recorded by the AWS provide information on the variability of net snow accumulation (e.g. Qin and others, 2004).

In both 2005 and 2006 the SSH records were most variable in winter (mid-April to end of September), and the short-term changes at these times (both accumulation and ablation events) were far greater than recorded in warmer months. We suspect this was a result of a problem with the sensor operation in the extremely low winter temperatures at Dome A (typically between $-50^{\circ} \mathrm{C}$ and $-80^{\circ} \mathrm{C}$ ). We have edited these data from the record. The SSH measurements are stable in the warmer months and consistent over the 2 years of record. In both 2005 and 2006 there was little snow accumulation from January through mid-April, and the major accumulation period was between October and December. The net accumulation in 2005 was $11 \mathrm{~cm}$ of snow, while in 2006 it was $5 \mathrm{~cm}$ of snow. We estimate the density of the surface snow at Dome A as $<0.2 \mathrm{~g} \mathrm{~cm}^{-3}$. Hence the net accumulation rate averaged over the 2 years was $1-2 \mathrm{~cm}$ w.e. $\mathrm{a}^{-1}$.

\section{Air pressure and wind}

Air pressures along the ice divide of East Antarctica (IDEA) are compared for the year 2005 (Fig. 4). Data at other sites along IDEA were obtained through the routine operational meteorological data exchange of the World Meteorological Organization's Global Telecommunication System (GTS). Monthly average air pressure at Dome A ranges between 570 and $592 \mathrm{hPa}$, with an annual mean value of $574 \mathrm{hPa}$. The annual mean air pressures at Dome $C$ and Vostok are 645 and $624 \mathrm{hPa}$ respectively. Air-pressure data for Dome F in 2005 are available only for 22 days in January. The average for this period was $611 \mathrm{hPa}$. Although the seasonal variations of air pressure at all these sites show a 'summer-high/winter-low' pattern, a secondary high appears in mid-June. The Antarctic atmosphere is cold and dry. There is a strong horizontal temperature gradient between the continent and the ocean, and a strong vertical temperature gradient (inversion) as a result of the intense radiative cooling during winter. For this reason, near-surface temperatures are particularly sensitive to low-level atmospheric circulation (Van den Broeke, 2000). The circumpolar trough of low pressure around Antarctica undergoes a strong semi-annual oscillation in strength and position. It is deepest and closest to the continent in the equinoctial months of March and September and this strongly impacts the seasonal variation of pressure at Antarctic coastal regions. The effect is weaker at high inland sites, but still present as seen in Figure 4.

Wind speed at Dome $A$ in most seasons is $<3 \mathrm{~m} \mathrm{~s}^{-1}$, and seldom greater than $5 \mathrm{~m} \mathrm{~s}^{-1}$ (Fig. 5). Low wind speeds also occur at other sites along IDEA, with a tendency for lower wind speeds at the higher sites, and higher wind speeds at lower sites (Fig. 5). But it is clear that the altitude is not the only factor determining wind speed along IDEA. Wind speed at Vostok is the highest among the four sites, yet its elevation is not the lowest; local topography is also an important factor determining surface wind along the ice divide.

There is no strong prevailing wind direction at Dome A (Fig. 5). Southerly winds account for $23 \%$, easterlies for $18 \%$, southeasterlies for $10 \%$ and north-northwesterlies for $8 \%$. The fact that there is no dominant wind direction suggests that, because Dome $\mathrm{A}$ is a summit region, a roughly symmetrical outflow of surface air is generated by the inflow occurring higher in the atmosphere.

\section{Glaciology}

\section{Densification processes}

A $110 \mathrm{~m}$ ice core was recovered at Dome A, and the density of this core was measured in situ using the weight-volume method. A total of 133 density values were obtained, primarily to determine the approximate depth where airbubble close-off occurs. The density profile is shown in Figure 6 , with the section of the ice core where the density varies between 0.81 and $0.85 \mathrm{~g} \mathrm{~cm}^{-3}$ shown in greater detail. Close-off depth was also deduced from $25 \mathrm{CH}_{4}$ measurements made on core samples from 86.5-110 m depth, and supported by diffusive column height estimates using $\delta^{15} \mathrm{~N}$ of $\mathrm{N}_{2}$. These show that

$$
\delta^{15} \mathrm{~N}=0.492 \pm 0.011(\%) \text {. }
$$




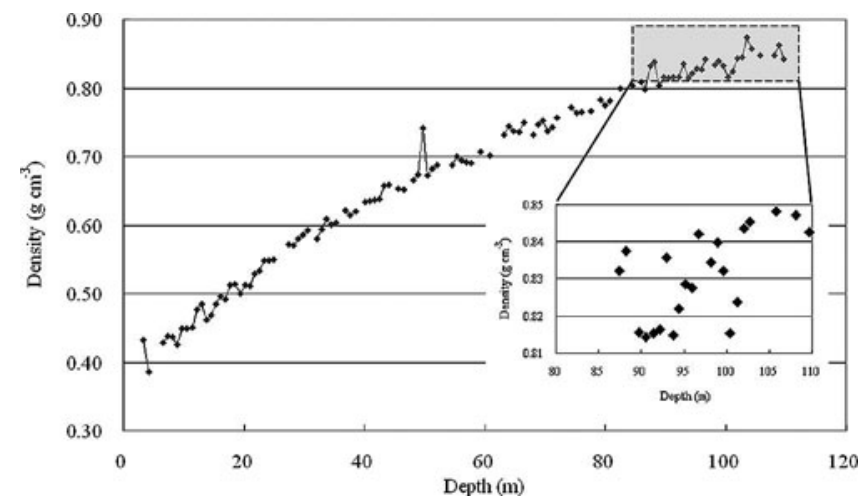

Fig. 6. Snow density profile along the $110 \mathrm{~m}$ firn core from Dome A. Densities at close-off depth, varying between 0.81 and $0.85 \mathrm{~g} \mathrm{~cm}^{-3}$, are shown in detail in the inset.

Using the temperature at Dome $\mathrm{A}\left(-58.3^{\circ} \mathrm{C}\right)$, we can calculate the diffusive column height $(\mathrm{DCH})$ given by $\delta^{15} \mathrm{~N}$ :

$$
\mathrm{DCH}=\delta^{15} \mathrm{~N} \times R \times \frac{T}{g}=89.6 \mathrm{~m},
$$

where $R$ is $8.314, T$ is the annual mean air temperature (K) and $g$ is the gravitational acceleration $\left(9.81 \mathrm{~m} \mathrm{~s}^{-2}\right)$. The DHC value is in very good agreement with the observed close-off depth of approximately 90-100 m, and suggests the absence of a convective zone.

\section{Snow accumulation rate estimated from reference horizons}

From the 2 years of AWS data discussed above, we estimate an accumulation rate of $0.01-0.02 \mathrm{~m}$ w.e. $\mathrm{a}^{-1}$. Detection of the 1954 atmospheric atomic bomb test horizon from beta activity and of the 1991 Pinatubo (Philippines) eruption from trace chemicals (non-sea-salt sulphate) in samples collected from a Dome A snow pit (Fig. 7) provide an estimated mean accumulation rate between 1954 and 2005 of $0.023 \mathrm{~m}$ w.e. $\mathrm{a}^{-1}$, in broad agreement with the AWS records. However, from the Pinatubo marker we estimate an average accumulation rate of around $0.034 \mathrm{~m}$ w.e. $\mathrm{a}^{-1}$ for the $1992-$ 2005 period, considerably greater than the 1965-2005 mean. This suggests that the Dome A accumulation may be quite variable at decadal scales.

Figure 8 shows contours of close-off depth on a plot of accumulation rate vs temperature for the Arnaud densification model (Arnaud and others, 2000). The location of Dome $A$ in this figure suggests an accumulation rate of $0.01-$ $0.02 \mathrm{~m}$ w.e. $\mathrm{a}^{-1}$. We ran the LGGE (Laboratoire de Glaciologie et Géophysique de l'Environnement) firn densification model (Goujon and others, 2003) with a surface temperature of $-58.3^{\circ} \mathrm{C}$ and different accumulation rate scenarios, until a

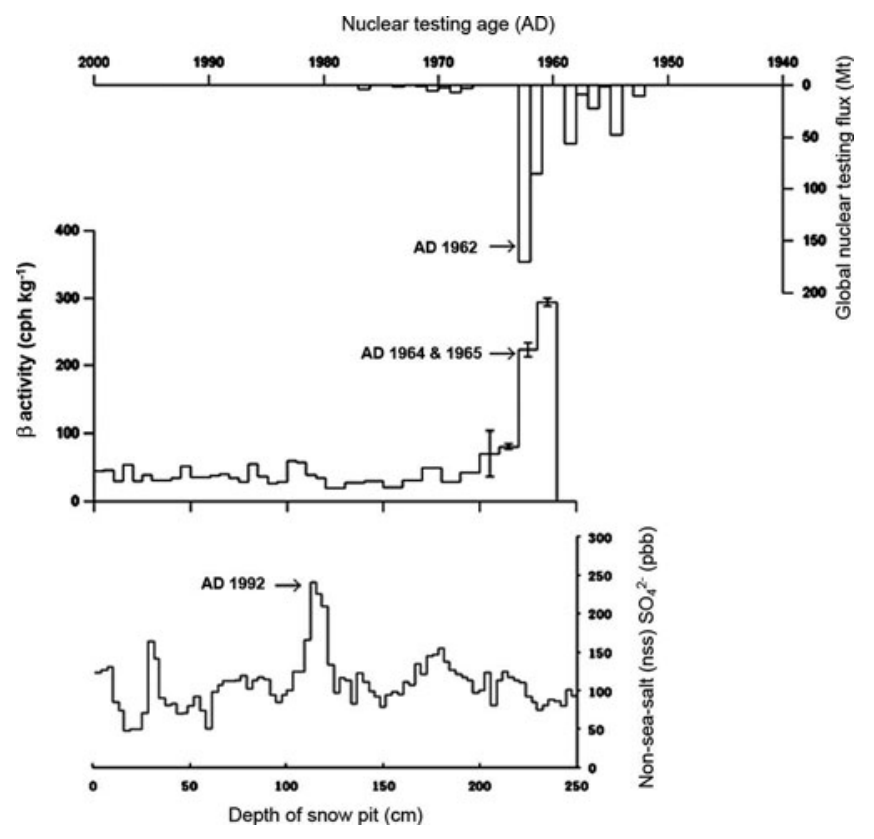

Fig. 7. Nuclear test and Pinatubo eruption events detected in a Dome A snow pit.

good match was obtained with the Dome A firn density profile measured in the field. The best match is obtained with a very low accumulation rate of $1.25-1.5 \mathrm{~cm}$ w.e. $\mathrm{a}^{-1}$. Such a low accumulation rate is comparable to the expected Last Glacial Maximum accumulation rates for Dome C and Vostok.

\section{CONCLUDING REMARKS}

The major criteria for a site for retrieval of the longest possible ice-core record are (1) deep ice, (2) low accumulation rate, (3) a summit with low horizontal ice velocity, and (4) a frozen base or low geothermal heat flux. Although we have no solid values for the heat flux beneath Dome A, no subglacial lakes or drainage systems have been detected here, suggesting that it is probably cold-based (Siegert and others, 1996, 2005; Lythe and others, 2001). Although melting occurs beneath other summits along IDEA, the geothermal heat flow may have large spatial variations (Dahl-Jensen and others, 2003) and there may be no melting under Dome A, where the bedrock is structurally (and probably geologically) different. The preliminary results from CHINARE-21 show that the Dome A area satisfies some of the core-site criteria, and it may be an ideal site to seek records extending back to at least $1 \mathrm{Ma}$. In Table 2, we present the parameters of the major ice-coring sites in

Table 2. Characteristics of ice-coring sites along IDEA

\begin{tabular}{|c|c|c|c|c|c|c|c|}
\hline Site & Location & $\begin{array}{l}\text { Elevation } \\
\text { ma.s.l. }\end{array}$ & $\begin{array}{c}\text { Annual mean temperature } \\
{ }^{\circ} \mathrm{C}\end{array}$ & $\begin{array}{c}\text { Thickness } \\
\text { m }\end{array}$ & $\begin{array}{l}\text { Accumulation } \\
\qquad \mathrm{g} \mathrm{cm}^{-2}\end{array}$ & $\begin{array}{l}\text { Current depth } \\
\text { m }\end{array}$ & $\begin{array}{l}\text { Age } \\
\text { ka }\end{array}$ \\
\hline Vostok & $72^{\circ} 28^{\prime} \mathrm{S}, 106^{\circ} 48^{\prime} \mathrm{E}$ & 3490 & -55.5 & 3750 & 2 & 3310 & 420 \\
\hline Dome F & $77^{\circ} 19^{\prime} \mathrm{S}, 39^{\circ} 42^{\prime} \mathrm{E}$ & 3810 & -54.3 & 3090 & 2.7 & 3029 & 730 \\
\hline Dome C & $74^{\circ} 39^{\prime} \mathrm{S}, 24^{\circ} 10^{\prime} \mathrm{E}$ & 3240 & -53.5 & 3270 & 2.7 & 3260 & 890 \\
\hline Dome A & $80^{\circ} 00^{\prime} \mathrm{S}, 7^{\circ} 21^{\prime} \mathrm{E}$ & 4092 & -58.3 & $>3050 ?$ & $1-2$ & - & - \\
\hline
\end{tabular}




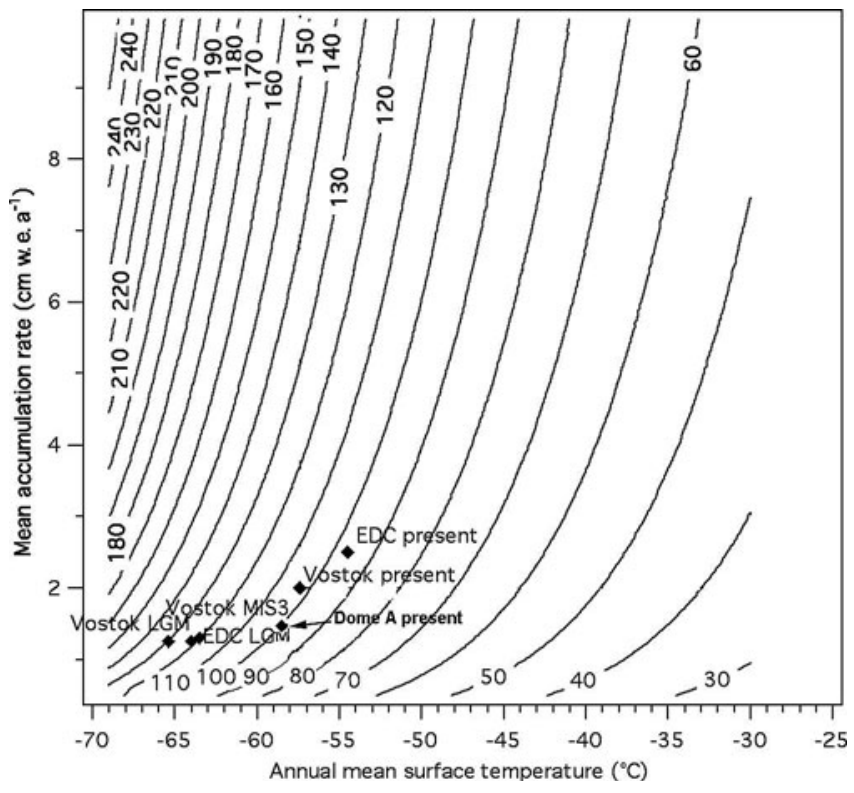

Fig. 8. Arnaud densification model based on the mean annual air temperature and surface snow accumulation rate. The contours represent the close-off depth.

Antarctica and compare them with Dome A to show why this site is special.

Further field-site survey studies are needed at Dome A to select an optimal drill site in the region. Comparative studies should also be made in other areas to determine the best overall location in Antarctica for retrieving a very old ice core. The International Polar Year (IPY) 2007-08 is initiating a new era in polar science, involving a wide range of research disciplines (Allison and others, 2007). The Prydz Bay-Amery Ice Shelf-Zhongshan-Dome A (PANDA) program is an endorsed project for IPY 2007-08. PANDA plans to undertake further site investigations at Dome $A$, including measurements of ice flow, ice thickness, densification processes and borehole/surface characteristics over a wider area around the dome. With the completion of PANDA and other related activities during IPY, scientists will have more detailed information for deciding the best location for deep ice-core drilling.

\section{ACKNOWLEDGEMENTS}

All members of inland traverses during CHINARE-21 are thanked for the coordinated fieldwork. This study is supported by the National Natural Science Foundation of China (NSFC: 40620120112), Chinese Academy of Sciences (CAS: KZCX3-SW-354) and the Hundred Talent Projects of CAS. This work was also supported by the Australian Government's Cooperative Research Centres (CRC) Program through the Antarctic Climate and Ecosystems CRC.

\section{REFERENCES}

Allison, I. and 25 others. 2007. The scope of science for the International Polar Year 2007-2008. Geneva, World Meteorological Organization. ICSU/WMO Joint Committee for IPY 2007-2008. (WMO/TD-No. 1364.)
Arnaud, L., J.M. Barnola and P. Duval. 2000. Physical modeling of the densification of snow/firn and ice in the upper part of polar ice sheets. In Hondoh, T., ed. Physics of ice core records. Sapporo, Hokkaido University Press, 285-305.

Brook, E.J., E. Wolff, D. Dahl-Jensen, H. Fischer and E.J. Steig. 2006. The future of ice coring: International Partnerships in Ice Core Sciences (IPICS). PAGES News, 14(1), 6-10.

Cafarella, L., S. Urbini, C. Bianchi, A. Zirizzotti, I.E. Tabacco and A. Forieri. 2006. Five subglacial lakes and one of Antarctica's thickest ice covers newly determined by radio echo sounding over the Vostok-Dome C region. Polar Res., 25(1), 69-73.

Clark, P.U. and 8 others. 2006. The middle Pleistocene transition: characteristics, mechanisms, and implications for long-term changes in atmospheric $\mathrm{pCO}_{2}$. Quat. Sci. Rev., 25(23-24), 3150-3184.

Dahl-Jensen, D., K. Mosegaard, P. Gogineni and H. Miller. 2003. Rapid spatial variations of the geothermal heat flow measured on the Greenland ice sheet. Geophys. Res. Abstr. 5, 11264.

EPICA community. 2004. Eight glacial cycles from an Antarctic ice core. Nature, 429(6992), 623-628.

Fujita, S. and 6 others. 1999. Nature of radio-echo layering in the Antarctic ice sheet detected by a two-frequency experiment. J. Geophys. Res., 104(B6), 13,013-13,024.

Goujon, C., J.M. Barnola and C. Ritz. 2003. Modeling the densification of polar firn including heat diffusion: application to close-off characteristics and gas isotopic fractionation for Antarctica and Greenland sites. J. Geophys. Res., 108(D24), 4792. (10.1029/2002JD003319.)

Johnsen, S.J. and 8 others. 2001. Oxygen isotope and palaeotemperature records from six Greenland ice-core stations: Camp Century, Dye-3, GRIP, GISP2, Renland and NorthGRIP. J. Quat. Sci., 16(4), 299-307.

Lythe, M.B., D.G. Vaughan and BEDMAP consortium. 2001. BEDMAP: a new ice thickness and subglacial topographic model of Antarctica. J. Geophys. Res., 106(B6), 11,335-11,351.

Martin, P.J. and D.A. Peel. 1978. The spatial distribution of $10 \mathrm{~m}$ temperatures in the Antarctic Peninsula. J. Glaciol., 20(83), 311-317.

Petit, J.R. and 18 others. 1999. Climate and atmospheric history of the past 420,000 years from the Vostok ice core, Antarctica. Nature, 399(6735), 429-436.

Qin, D. 1987. Densification process of snow/firn in the surface layer of the Antarctic ice sheet. J. Glaciol. Geocryol., 9(3), 190205. [In Chinese with English summary.]

Qin, D. and 6 others. 2004. Snow surface height variations on the Antarctic ice sheet in Princess Elizabeth Land, Antarctica: 1 year of data from an automatic weather station. Ann. Glaciol., 39, 181-187.

Raymo, M.E. and W.F. Ruddiman. 1992. Tectonic forcing of late Cenozoic climate. Nature, 359(6391), 117-122.

Rybak, O. and P. Huybrechts. 2003. A comparison of Eulerian and Lagrangian methods for dating in numerical ice-sheet models. Ann. Glaciol., 37, 150-158.

Siegert, M.J. and J.A. Dowdeswell. 1996. Spatial variations in heat at the base of the Antarctic ice sheet from analysis of the thermal regime above subglacial lakes. J. Glaciol., 42(142), 501-509.

Siegert, M.J., S. Carter, I. Tabacco, S. Popov and D.D. Blankenship. 2005. A revised inventory of Antarctic subglacial lakes. Antarct. Sci., 17(3), 453-460.

Van den Broeke, M.R. 2000. On the interpretation of Antarctic temperature trends. J. Climate, 13(21), 3885-3889.

Zhang, S., E. Dongchen, Z. Wang, C. Zhou and Q. Shen. 2007. Surface topography around the summit of Dome A, Antarctica, from real-time kinematic GPS. J. Glaciol., 53(180), 159-160. 